\title{
The Influence of the Plastic Bags on the Environment
}

\begin{abstract}
VALENTINA CONSTANTA TUDOR ${ }^{1}$, ANCUTA MARIN ${ }^{2}$, DIANA ZAMFIR VASCA ${ }^{1}$, MARIUS MIHAI MICU' ${ }^{1}$, DRAGOS ION SMEDESCU*
'University of Agronomic Sciences and Veterinary Medicine of Bucharest, 59 Marasti Blvd, 011464, Bucharest, Romania

${ }^{2}$ Research Institute for the Economy of Agriculture and Rural Development, 61 Marasti Blvd, Bucharest, romania

It is known, as well as a rule, that plastic materials can not instictively and naturally degrade when released into the environment. Due to the persistence of plastics to degradation and also to propagation in industry, the problem of plastic pollution has progressed considerable in order to become a threat to global ecology, on land and sea. The present study presents a global mapping of actions brought in to reduce the use of plastic, plastic bags and foamed plastic products, followed by selected case studies from each region of the world, with more attention offered to the European Union countries and the strategies elaborated by them to provide a cleaner and safer environment.
\end{abstract}

Keywords: plastic bags, environment, plastic pollution

After the second world war, a new category of advantageous materials has been implemented whose properties can be customized through control of their syntheses and processing to fit every desired application. With a yearly production of over 200 million tons, plastics form a pillar of the economy without which today's principle of living would not be attainable. [13].

Polyethylene, the most widely used plastic, was accidentally born in 1933 at a factory in Northwich, England. In 1965 , the plastic bags patented by Celloplast, a Swedish company, were born and managed to gain ground and gradually replace the fabric in Europe.

Since 1980, plastic bags have had a market share of $80 \%$ in Europe and have spread rapidly in the United States. In 1982, two major American supermarkets, Safeway and Kroger, moved from paper bags to plastic bags, and then replaced all over the world.

Waste is not only a threat to the environment, but it is increasingly a menace to human health and their way of life [18].

From birth to the firstenvironmental problems reported, there was little, so in 1997, Charles Moore signaled the first environmental problems in the Pacific Ocean. Less than $10 \%$ of the plastic ever produced has been recycled, so all governments should consider banning or taxing single-use food pouches or containers to eliminate such a wave of pollution [21]. Bangladesh, in 2002, was the first country to ban thin plastic bags after it was found that they played an important role in drained drainage systems during disastrous floods.

Considering the increase in global consumption and their natural resistance to degradation, plastics and their accumulation in the environment are a growing concern. China is the largest source of plastic packaging waste, followed by the European Union and the United States.

Per capita, however, the United States ranks first in the world with regard to waste generation, with J apan and the EU ranked the first. In view of this, it has occasionally been attempted to influence consumer behavior by imposing product taxes reflecting the external costs imposed by such products that are not originally included in their price. According to Frank Convery and Simon McDonnell, the effect of the tax on the use of plastic bags in retail outlets was amazing - a reduction in the use of the order of $90 \%$ and an associated gain in the form of low waste and negative environmental effects.

Pollution is a complex phenomenon most frequently involved in disturbing the balance of environmental compounds that affect health biocenosis [9].

Pollution atmosphere has the biggest repercussion on the environment due to the quantity and diversity of pollutants and due to deterioration of geographical areas. Air pollution, portray a globally problem whose time scale is highlighting the greenhouse effect and the destruction of the ozone layer stratospheric. [14].

Internationally, there is increasing evidence of the cumulative impact that plastic has on soils, waterways, marine environments and fauna [22]. The economic damage caused by plastic waste is vast.

Plastic litter in the Asia-Pacific region alone costs its tourism, fishing and shipping industries $\$ 1.3$ billion per year. In Europe, cleaning plastic waste from coasts and beaches costs about euro 630 million per year.

Studies suggest that the total economic damage to the world's marine ecosystem caused by plastic amounts to at least $\$ 13$ billion every year. The economic, health and environmental reasons to act are clear [23]. Plastic bag bans, if properly planned and enforced, can effectively counter one of the causes of plastic overuse.

\section{Experimental part}

Plastic is a miracle material. Thanks to plastics, countless lives have been saved in the health sector, the growth of clean energy from wind turbines and solar panels has been greatly facilitated, and safe food storage has been revolutionized.

Learning from the experience of countries that have introduced bans and regulations on single-use plastics, this assessment analyses what has worked well, what hasn't, and why. Plastic isn't the problem, it's what we do with it, and this means that the duty is on us to be far smarter in how we use this miracle material.

The most common single-use plastics found in the environment are, in order of importance, cigarette butts, plastic drinking bottles, plastic bottle caps, food wrappers, plastic grocery bags, plastic lids, straws and stirrers, other types of plastic bags, and foam take-away containers. All these represent the waste products of a throwaway culture

* email: smedescudragos@yahoo.com 
that treats plastic as a insignificant material rather than a valuable resource to be exploit [23].

Environmental pollution represents an important and complex subject with a huge concern for scientists in different fields, but also for the governments, national and international organizations, because besides the incontestable assets of the industry for the human development, it has negative effects to the human health [3].

For a good understanding of the issues discussed it is necessary to define and explain the processes of biodegradation, composting and oxo-degradation.

Biodegradation is a process by which material disintegrates and is decomposed by micro-organisms into elements that are found in nature, such as $\mathrm{CO}_{2}$, water and biomass.

Biodegradation can occur in an oxygen rich environment (aerobic biodegradation) or in an oxygen poor environment (anaerobic biodegradation). There is currently insufficient evidence to provide assurance that oxo-degradable plastic, including plastic carrier bags, will biodegrade in the environment within reasonable time [24].

Recycling waste can be considered the key element of the entire environmental issues, including giving it some solutions on the conservation of natural resources and energy, and in terms of preserving a healthy and unpolluted habitat in all aspects [18].

\section{Results and discussions}

It is too early to draw robust conclusions on the environmental impact that bans and levies have had. In 50 per cent of cases, information about their impact is missing, partly because some countries have adopted them only recently and partly because monitoring is deficient.

In countries that do have data, about 30 per cent have registered notable decrease in the consumption of plastic bags within the first year. The remaining 20 per cent of countries have reported little to no change.
Since the 1950's, growth in the production of plastic has largely surmounted that of any other material, with a global shift from the production of durable plastics to single-use plastics (including packaging), as shown in figure 1.

Unfortunately, the production of plastic is largely based on fossil hydrocarbons, which are non-renewable resources. If the growth in plastic production continues at the same level, by 2050 the plastic industry may account for $20 \%$ of the world's total oil consumption [23].

Global consumption of plastic can be estimated by observing the amount of plastic waste produced. Plastic packaging is mostly single-use, especially in business-toconsumer applications, and a majority of it is discarded the same year it is produced.

In 2015, plastic packaging waste accounted for $47 \%$ of the plastic waste generated globally, with half of that appearing to come from Asia. While China remains the largest worldwide generator of plastic packaging waste, the USA is the largest generator of plastic packaging waste on a per-capita basis, followed by apan and the EU (fig. 2)

\section{International action on bags}

Government-led changes to reduce plastic bag consumption and litter are common internationally. Bans and levies are the most popular methods for plastic bag reduction globally (fig. 3).

In the EU, we currently use 100 billion plastic bags per year. This is a huge waste, because most of the time the bags are used only once, many ending in our oceans and seas.

A new measure in combating this problem raised by plastic consumption is the new EU Plastic Packaging Directive, which obliges Member States to drastically reduce the use of light bags.

Due to the measures taken in recent years in Denmark and Finland, the average annual consumption of lightweight plastic bags is only four per person. In Ireland, since the introduction of a tax in 2002 , the consumption of disposable plastic bags decreased from 328 people per

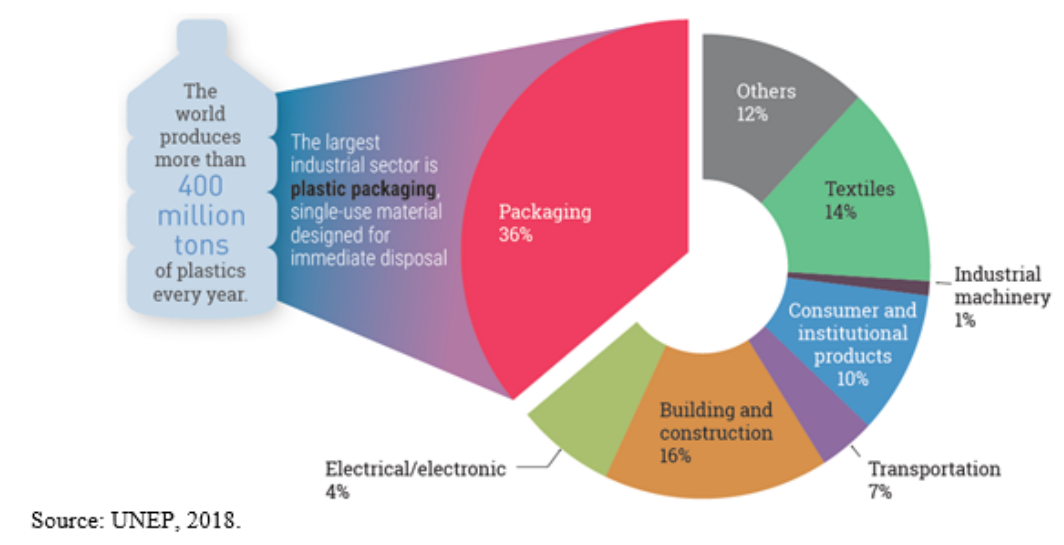

Fig. 1. Global plastic production by industrial sector, 2015

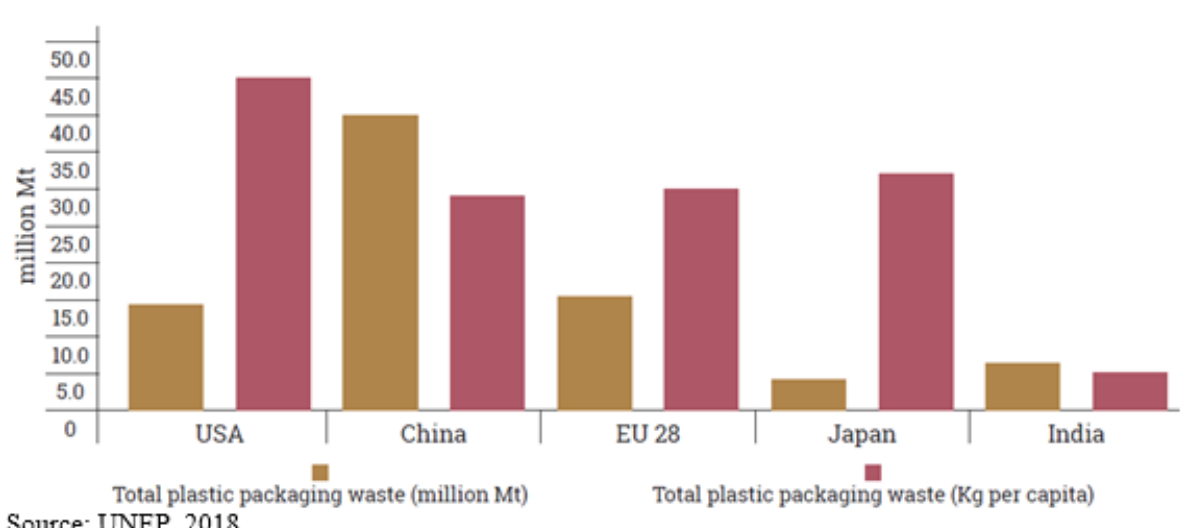

Fig. 2. Plastic packaging waste generation, 2015, million Mt 


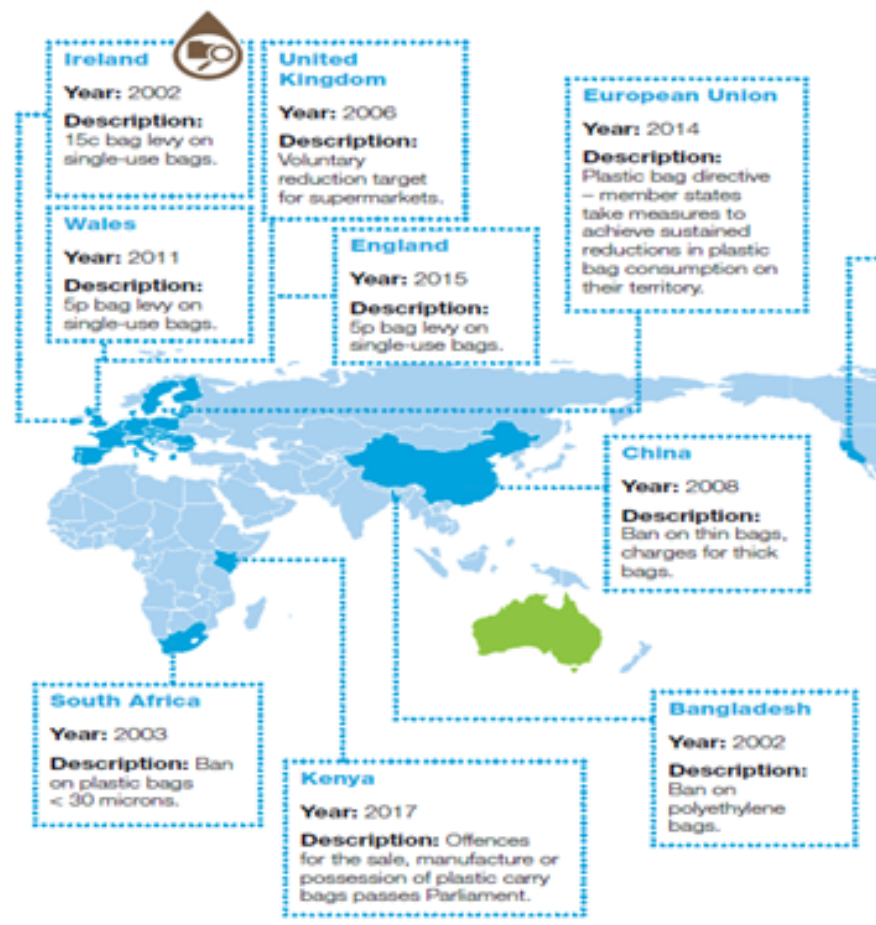

year to just 18, representing a downgrading of almost $95 \%$. At the other end of the ranking there are countries where the use of bags in 2010 was well above average - for example, 269 bags in Greece and 421 in Bulgaria [24].

Defending the environment in Romania, it is a subject of great significance both for the present and especially for the future [4].

Table 1

REGULATIONS IN THE EUROPEAN UNION

One of the principal aspects of the waste management policies is to decrease the quantity of litter disposed to landfills and to recycle the organic matter [19].

In recent times, the connection between economic growth and environmental protection has become progressively significant. Economic production creates pollutant emissions whose environmental impact is moderated by abatement activities financed by government expenditure [8].

\begin{tabular}{|c|c|}
\hline BELGIUM & $\begin{array}{l}\text { - In the Walloon region has been legislated a decree which forbids the use of } \\
\text { carrier bags since 2016; } \\
\text { - Until January } 2019 \text {, plastic bags with a bio sourced content of at least } 40 \% \text { are } \\
\text { conceded for food packaging. } \\
\text { - In the Brussels region, has been legislated a decree which forbids plastic } \\
\text { carrier bags since September } 2017 \text {. }\end{array}$ \\
\hline FINLAND & $\begin{array}{l}\text { - The Ministry of Environment has developed an "Green Deal agreement" in } \\
\text { which the government and business sectors agree on the compliance with } \\
\text { sustainability aspects; } \\
\text { - The first "Green Deal agreement" was employed with the Finnish Trade } \\
\text { Association. Its purpose is to reduce the consumption of plastic carrier bags. }\end{array}$ \\
\hline FRANCE & $\begin{array}{l}\text { - Since } 1 \text { July 2016, single use lightweight plastic bags are outlawed at cashiers; } \\
\text { - Since } 1 \text { January } 2017 \text {, this kind of bags are also banned for the packing of } \\
\text { goods at the point of sale, and only the lightweight plastic bags made of bio- } \\
\text { plastics are allowed. }\end{array}$ \\
\hline GERMANY & $\begin{array}{l}\text { - A free-willed concession between the German Federal Environment Ministry } \\
\text { and the German Trade Association introduced on } 1 \text { July 2016, involves a fee for } \\
\text { carrier bags (50cents/1 euro). }\end{array}$ \\
\hline ITALY & $\begin{array}{l}\text { - In } 2011 \text {, has been introduced a law stating that single use plastic shopping bags } \\
\text { dispensed by retail stores must be from biodegradable plastics. }\end{array}$ \\
\hline NETHERLANDS & $\begin{array}{l}\text { - On January 2016, has been introduced a mandatory fee of } 0.25 \text { euros per } \\
\text { plastic bag. }\end{array}$ \\
\hline SPAIN & $\begin{array}{l}\text { - Since } 1 \text { July 2018, all plastic bags are charged; } \\
\text { - From } 2020 \text { on, thicker bags must have a recycled plastic content of at least } \\
\text { - } 50 \% \text {. }\end{array}$ \\
\hline SWEDEN & $\begin{array}{l}\text { - The 2016:1041 regulation on plastic carrier bags states that businesses and } \\
\text { operators who provide plastic carrier bags to their consumers have the } \\
\text { responsibility to inform the environmental impact of plastic carrier bags; }\end{array}$ \\
\hline UK & $\begin{array}{l}\text { - On } 5 \text { October, in England has been introduced a mandatory fee for plastic } \\
\text { carrier bags applying to businesses with } 250 \text { or more employees; } \\
\text { - Wales introduced in } 2011 \text { a mandatory fee which includes paper carrier bags; } \\
\text { - Northern Ireland followed in } 2013 \text { and Scotland in } 2014 \text {. }\end{array}$ \\
\hline
\end{tabular}

Source: *s*https://www.thepaperbag.org/for-compliance-with-the-law/regulations-in-eu/ 
Environmental pollution represents one of the most discussed problems of current times and one of the first orders for contemporary's societies [1].

As regards the new plastic bags directive, national governments must ensure that by the end of 2019, not more than 90 lightbags per person per year are consumed, and by the end of 2025 this figure should drop to 40 bags each. To achieve these objectives, different measures are being implemented.

\section{Regulations in the European Union}

Nowadays, the average EU citizen consumes 198 plastic carrier bags per year. After the Directive 2015/270 with reference to the consumption of lightweight plastic carrier bags has been enacted, the national governments of the member states have introduced some regulations in their countries on order to reduce the consumption (table 1) [25].

The production of plastic increased from 0.5 million tons in 1950 to over 260 million tons now [6]. Plastics are found in all areas of activity because they are lightweight, inexpensive, hygienic, adaptable, easy to process durable and resistant to environmental factors. Even that, what represents the main qualities of plastics, namely durability and resistance to environmental factors, in reality, represents their major defect because those does not degrade easily, being necessary even some decades [15]. Plastics due to their versatility become the essential ingredients to provide a quality to life. The accumulation of plastics in the environment is a matter of great concern leading to long-term environment, economic and waste management problems [8].

Over the past decade, a remarkable number of local, sub-national and national governments have passed legislation to ban or severely restrict the use of plastic shopping bags. Legislation against plastic bags has occurred at a number of jurisdictional levels, from villages and cities, to states and entire countries [5]. Free of charge plastic carrier bags have practical advantages for consumers but they also involve adverse environmental impacts. For example, plastic bags are made of nonrenewable resources (petroleum), which takes hundreds of years to degrade, and plastic bags usually contain additives that pollute the ground and water when released by action of humidity and ultraviolet radiation [7].

Plastic pollution is the dominant type of anthropogenic debris ubiquitous throughout the marine environment [6]. Annual, Europeans generate 25 million tons of plastic waste, but less than $30 \%$ are collected for recycling. Worldwide, $85 \%$ of the plastic waste comes from the beaches. Plastic comes even into our lungs and our tables, and the health effects of microplastics in the air, water and food are still unknown [26]. Prevention represents those activities designed to reduce the probability of occurrence of the risk events or the estimated negative effects.

Unless we change the way we produce and use plastics, by 2050 there will be more plastics than life in our oceans. This is a challenge that citizens, industry and governments need to address together [17]. The input-side on the left shows that 8 billion tons of materials are processed into energy or products annually in the EU. Only 0.6 billion tons originate from recycling.

On the output-side, it shows that out of the 2.2 billion tons of waste that are generated only 0.6 billion tons reenter the system as recycled materials. The rest of the materials, equivalent to 1.5 billion tons, is waste.

These aspects point to a significant potential for improvement in particular by increasing the share of materials recycled as secondary raw materials and decreasing the production of waste [20].

\section{Conclusions}

Plastic waste has become a worldwide problem. The regulation of the European Union has some challenges that are linked to production and consumption, and the most important thing that should be take in consideration is the end of life of plastics and most important, of plastic bags.

The European Union, has developed an ambitious strategic vision, which is covering the entire value chain, which can provide growth, can create jobs and also bring innovation. At the same time, it can make the transition to a low-carbon and to a circular economy offering the citizens a safer and a cleaner environment.

\section{References}

1.BALACEANU C.M., MITIU M.A., MARCUS M.I., MINCU M., Pollution Impact of the Grozavesti Thermoelectric Power Plant on the Urban Agglomeration Bucharest, Rev.Chim. (Bucharest), 69, no. 2, 2018;

2.BALJIT S., NISHA S., (2008). Mechanistic implications of plastic degradation, Polymer Degradation and Stability p. 93;

3.CAPATINA, C., CIRTINA, D., Comparative study regarding heavy metals content in air from Targu Jiu and Rovinari) Rev. Chim.(Bucharest), 68, no. 12, 2017.

4.CHIVU O.R., SEMENESCU A., BABIS C., IACOBESCU G., NEGOITA O. D., GRADINARU S., Theoretical and Experimental Research in Order to Protect the Environment in Romania, Rev.Chim.(Bucharest), 68, no. 8, 2017;

5.CLAPP J., SWANSTON L., (2009). Doing away with plastic shopping bags: international patterns of norm emergence and policy implementation, Environmental Politics, 18:3, 315-332, DOI: 10.1080/ 09644010902823717;

6.ERIKSEN M., THIEL M., MAXIMENKO N., LATTIN G., (2013). Plastic pollution in the South Pacific subtropical gyre, Marine Pollution Bulletin no. 68(2013), p. 71-76, https://www.sciencedirect.com/science/article/ pii/S0025326X12006224?via\%3Dihub https://ec.europa.eu/environment/ efe/themes/economics-strategy-and-information/ambitious-newstrategy-make-plastic-fantastic_en

7.J AKOVCEVIC A., STEG L., MÄZZEO N., CABALLERO R., FRANCO P., PUTRINO N., FAVARA J ., (2014). Charges for plastic bags: Motivational and behavioral effects, J ournal of Environmental Psychology, No. 40, 2014, 372-380, https://www.sciencedirect.com/science/article/pii/ S0272494414000863?via\%3Dihub;

8.LADARU, G. R., DRACEA, R., Influence of the Environmental Protection Expenditure Dynamics on the Economic Growth in Romania During 2008-2015, Rev. Chim.(Bucharest), 68, no. 9, 2017, p. 1392 9.MANEA, I., MANEA, L.C., Study on the Content of Polycyclic Aromatic Hydrocarbons in the Water from the Industrial Area, Rev. Chim.(Bucharest), 61, no. 12, 2010

10.MOCUTA, D.N. Methods and Instruments of Assessing the Life Quality, 28th International Business-Information-ManagementAssociation Conference, 2016;

11.MOCUTA, D.N. Influence of the Climate Changes on the Human Life Quality, in Rural Areas, Rev.Chim.(Bucharest), 68, no. 6, 2017;

12.MOCUTA, D. N., Dimensions And Limits Of The Human Health Economics, International Economic Conference, Romania Within The Eu: Opportunities, Requirements And Perspectives, VOL I, Romania, 2007

13.PIRINGER, 0., Prediction of Diffusion Coefficients in Plastic Materials, Rev.Chim.(Bucharest), 59, no. 11, 2008

14.RUSANESCU, C. O., JINESCU, C., RUSANESCU, M., BEGEA, M., GHERMEC, O., Evaluation of Air Pollution by NO2, SO2, PM10 in Bucharest, Rev. Chim.(Bucharest), 69, no. 1, 2018, p. 101

15.TEODORESCU N.I., STEFANESCU F.I., (2016). Influenka reciclarii deseurilor din materiale plastice asupra proprietatilor acestora referitoare la mediu, Asociatia Generala a Inginerilor din Romania, lucrarile celei de-a VII-a editie; 
16.THOMPSON R.C., MOORE C.J., VOMSAAL F.S., SWAN S.H., (2009). Plastics, the environment and human health: current consensus and future trends, Philosophical Transactions of the Royal Society B: Biological Sciences, 364, 2153-2166;

17.TIMMERMANS F., (2018). Ambitious new strategy to make plastic fantastic, Magazine Environment for Europeans, 2018.

18.UNGUREANU, G., IGNAT, G., LEONTE, E., COSTULEANU, C.L., JITAREANU, S., DONOSA, D., TEODORESCU, SOARE E. , SANDU, I.G., (2018). Management of Urban Organic Solid Waste Applied in Romanian Metropolitan City, Rev. Chim.(Bucharest), 69, no. 6, 2018, p. 1585

19.UNGUREANU G., IGNAT G., VINTU C. R., DIACONU C. D., SANDU I. G., Study of Utilization of Agricultural Waste as Environmental Issue in Romania, Rev.Chim. (Bucharest), 68, no. 3, 2017, p. 570 20.***European Commission, (2018).

http://ec.europa.eu/environment/circular-economy/pdf/monitoringframew ork.pdf;
21.***U.N. World Environment Day, (2018), https://www. unenvironment.org/events/un-environment-event/worldenvironment-day-2018

22.*** Government of Western Australia, (2017). Implementing a lightweight single-use plastic bag ban in Western Australia, Department of Water and Environment Regulation, www.dwer.wa.gov.au, p. 8; 23.***UNEP, (2018). Single-use plastics: A Roadmap for Sustainability, p. 3, https://wedocs.unep.org/bitstream/handle/20.500.11822/25496/ singleUsePlastic_sustainability.pdf?isAllowed $=y \&$ sequence $=1$ 24.***European Commission, (2018), Report from the Commission to the European Parliament and the Council on the impact of the use of oxo-degradable plastic, including oxo-degradable plastic carrier bags, on the environment;

25.***https://www.thepaperbag.org/for-compliance-with-the-law/ regulations-in-eu/

26.***European Commission, (2018). http://europa.eu/rapid/pressrelease_IP-18-5_ro.pdf

Manuscript received: 11.08 .2018 